\title{
Role of DDC-4/sFRP-4, a secreted Frizzled-related protein, at the onset of apoptosis in mammary involution
}

\author{
MD Lacher ${ }^{1}$, A Siegenthaler ${ }^{1}, \mathrm{R}$ Jäger $^{2}, \mathrm{Xi}$ Yan $^{1}$, S Hett ${ }^{1}$, \\ L Xuan ${ }^{1}$, S Saurer ${ }^{1}$, RR Lareu ${ }^{3}$, AM Dharmarajan ${ }^{3}$ and R Friis*,1 \\ 1 Department of Clinical Research, University of Berne, Tiefenaustrasse 120, \\ $\mathrm{CH}-3004$ Bern, Switzerland \\ 2 Institute for Pathology, University Clinic Bonn, Sigmund Freud Str. 25, D-53127 \\ Bonn, Germany \\ ${ }^{3}$ School of Anatomy and Human Biology, University of Western Australia, 35 \\ Stirling Highway, Crawley, Western Australia 6009, Australia \\ * Corresponding author: R Friis, Department of Clinical Research, University of \\ Berne, Tiefenaustrasse 120, CH-3004 Bern, Switzerland. Tel: +41-31-308- \\ 8011; Fax: +41-31-308-8028; E-mail: robert.friis@ dkf3.unibe.ch
}

Received 8.8.02; revised 19.11.02; accepted 25.11.02 Edited by J Tilly

\begin{abstract}
Using differential display, we isolated DDC-4, a secreted frizzled-related protein (sFRP), which is induced in the physiological apoptosis of hormonally regulated, reproductive tissues such as mammary gland, prostate, corpus luteum and uterus. The role of this gene in apoptosis was studied in animals overexpressing ectopic DDC-4/sFRP-4. Transgenic mice bearing the $D D C-4 / s F R P-4$ CDNA under the control of the MMTV-LTR promoter showed lactational insufficiency and many apoptotic cells in the alveoli between day 19 of pregnancy and day 4 of lactation as demonstrated by TUNEL reaction and the presence of activated caspase-3. We performed a PKB/Akt kinase assay and studied several of its substrates using phosphorylation-specific antibodies to show reduced phosphorylation in PKB/Akt itself, as well as in glycogen synthetase kinase-3 $\beta$ (GSK-3 $\beta$ ), BAD, and Forkhead. Taken together, our results show a role for DDC-4/sFRP4 in abrogating an epithelial cell survival pathway at the onset of mammary gland involution.

Cell Death and Differentiation (2003) 10, 528-538. DOI:10.1038/ sj.cdd. 4401197
\end{abstract}

Keywords: sFRP-4; mammary gland; transgenic mice; apoptosis; caspase-3; PK-B/Akt; BAD; Forkhead; GSK-3 $\beta$

Abbreviations: FRP, secreted frizzled-related protein; GSK-3 $\beta$, glycogen synthetase kinase- $3 \beta$; DDC, differential display coincidence; APC, Adenomatous polyposis coli.

\section{Introduction}

The phenomenon of programmed cell death is particularly prominent in the reproductive cycle of the mammary gland. During pregnancy, the mammary epithelium proliferates profusely, but full differentiation is achieved at lactation. Following weaning, the differentiated mammary epithelium, no longer needed, involutes by a process of programmed cell death, returning essentially to the resting state. Our research employs this physiological model for programmed cell death in the mouse, taking advantage of this rapid and synchronous involution of the normal mammary gland to study the processes of programmed cell death. This programmed cell death takes the form of apoptosis. ${ }^{1,2}$

We were interested in identifying genes involved in the control and execution of mammary gland apoptosis. ${ }^{2,3}$ Since the process of mammary involution is complex, comprising a tissue remodeling program that proceeds in parallel with programmed cell death, a differential display coincidence (DDC) method was employed to recognize genes upregulated in common between two models of physiological apoptosis: the involuting mammary gland and the prostate following castration. ${ }^{3}$ One of the most interesting genes isolated, $D D C$ 4 , showed striking homology to the ligand-binding domain of several frizzled family, 7-pass transmembrane receptors. $D D C$-4 was subsequently recognized as encoding a product belonging to the secreted frizzled-related protein (sFRP) subfamily, ${ }^{4}$ and is referred to here as DDC-4/sFRP-4.

Frizzled proteins are cell surface receptors for Wnt/Wingless (Wg) ligands. In this well-characterized pathway, Wnt/Frizzled signal transduction targets a key cellular regulatory molecule, $\beta$-catenin, which is mainly sequestered with $\mathrm{E}$-cadherin at the cell membrane. The small amounts of free $\beta$-catenin that occur in the cell are normally degraded in the adematous polyposis coli (APC) pathway, thus limiting the availablity of $\beta$-catenin to act as a cofactor for transcription factors of the Tcf-Lef family. ${ }^{5}$ Wnt/Frizzled signaling acts to brake the degradation of $\beta$ catenin, thus increasing levels of the free regulator and activating the Tcf-Lef-dependent transcription of a set of genes including c-myc, ${ }^{6}$ cyclin $D 1,{ }^{7,8}$ and $c-j u n .{ }^{9}$ Interestingly, hyperactivity of the $\mathrm{Wnt} / \beta$-catenin signaling pathway has been linked to several malignancies in man. ${ }^{10}$

Whereas the Wnts are a diverse family of insoluble, extracellular matrix-associated proteins, the 7-pass transmembrane Frizzled receptors are both diverse and promiscuous in their specificity for the Wnt ligands. ${ }^{11}$ The sFRPs ${ }^{12,13}$ are tightly regulated at the transcriptional level ${ }^{14}$ and presumably play a modulatory role by competing with the closely related receptor Frizzled for the Wnt ligands. This allows the system to respond rapidly to changing stimuli; the sFRPs can rapidly quench a locally pre-existing signaling field. 
a

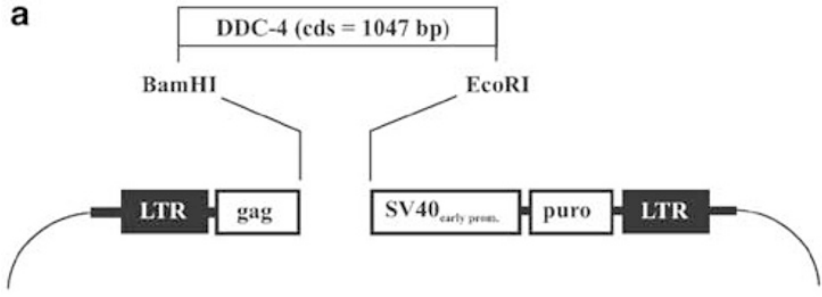

b

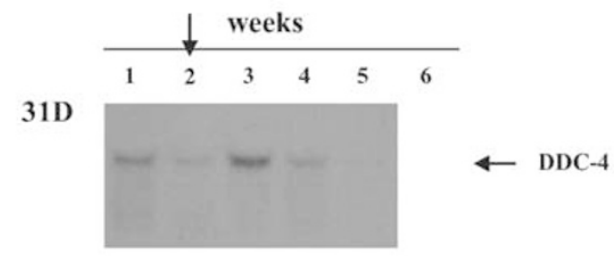

$30 \mathrm{~F}$

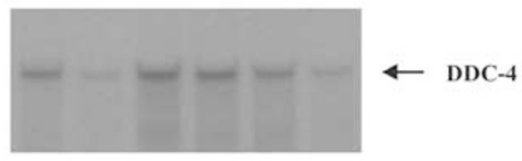

C

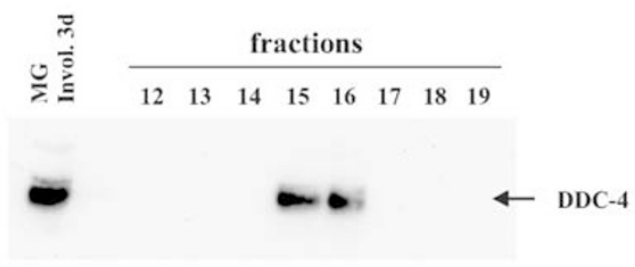

Figure 1 (a) Schematic representation of the $D D C-4$ retroviral construct. (b) Northern blot analysis of $D D C-4 / s F R P-4$ expression in retrovirally infected line 31D and 30F mammary cells after different times in culture. Each track was loaded with $5 \mu \mathrm{g}$ total RNA. The arrow indicates the time of the last selection with puromycin. (c) Western blot analysis using affinity-purified, polyclonal rabbit antiDDC-4 antibody to detect DDC-4/sFRP-4 secreted into cell culture supernatants. Peak elution of DDC-4/sFRP-4 from a heparin-Sepharose affinity column was at $420 \mathrm{mM} \mathrm{KCl}$. A culture supernatant $(10 \mathrm{ml})$ from DDC-4/sFRP-4, retrovirally infected clone $30 \mathrm{~F}$ cells was passed over the column and eluted in $1 \mathrm{ml}$ fractions. MG: extract of 3 day involuting mouse mammary gland as positive control

Since the upregulation of DDC-4/sFRP-4 has been seen associated with physiological apoptosis in several contexts, the obvious question is whether it is causally involved in initiating apoptosis.

\section{Results}

To address this question we have used two different but complementary experimental designs. The first approach consisted of local release of DDC-4/sFRP-4 protein by implanting DDC-4/sFRP-4 overexpressing cells into the mammary gland to disturb the local balance between Wnt to Frizzled receptor interaction. The second approach involved the establishment of DDC-4/sFRP-4 transgenic mice taking advantage of the MMTV-LTR promoter for mammary glandspecific transgene expression. ${ }^{15}$

\section{Establishment of cell lines overexpressing DDC-4/ sFRP-4}

For gene transfer of $D D C$-4, we prepared a $D D C-4-\mathrm{pBabe} \mathrm{puro}^{\text {pur }}$ construct containing the full-length coding sequence of the
$D D C-4 / s F R P-4$ secreted frizzled-related gene, which has been shown by in vitro translation to encode a protein of the expected length. ${ }^{4}$ The retroviral construct is shown schematically in Figure 1a. Using the BOSC 'helper' packaging cells, ${ }^{16}$ retroviral titres of $2 \times 10^{5}$ infectious units $/ \mathrm{ml}$ were obtained. The mammary gland-derived cell lines $31 \mathrm{D}$ and $30 \mathrm{~F}$ as well as primary mammary fibroblasts were infected with this construct and selected with puromycin. Northern blot analysis was employed to monitor expression from the DDC-4/sFRP-4 retroviral construct in the infected cells. The infected epithelial $31 \mathrm{D}$ cells exhibited strong expression of $D D C-4 / \mathrm{sFRP}-41$ week after infection. Expression, however, was downregulated already by 3 weeks in culture (Fig 1b). In contrast, retroviral expression of $D D C-4 / s F R P-4$ was maintained at high levels for up to 6 weeks in the infected fibroblast-like 30F cells (Figure 1b) as well as in primary mammary gland-derived fibroblasts (data not shown). Figure 1c shows a Western blot of cell culture supernatants using affinity-purified, polyclonal rabbit anti-DDC4 antibody indicating secretion of the DDC-4/sFRP-4 protein into the culture media by the infected $30 \mathrm{~F}$ cells. Culture supernatants were applied to a heparin-Sepharose column and DDC-4/ sFRP-4 was eluted with a salt gradient peaking at $420 \mathrm{mM} \mathrm{KCl}$. In parallel experiments with cell lysates, less amount of DDC-4/ sFRP-4 was found to be cell associated (data not shown). Over an observation time of 8 weeks, we did not observe any phenotypic consequences of retroviral DDC-4/sFRP-4 expression in vitro in any of the infected cells with regard to induction of apoptosis or reduced growth rate (data not shown).

\section{Local overexpression of DDC-4/sFRP-4 in the mammary gland}

We planned to study the effect of DDC-4/sFRP-4 overexpression using the mammary epithelial reconstitution approach involving removal of the mammary epithelial anlage from normal, 3-week-old mice and replacement with ex vivo infected mammary epithelial cells. ${ }^{17}$ For this approach, however, transgene expression must be maintained for some weeks. The rapid downregulation of the integrated retroviral expression in the epithelial 31D cells discouraged us from attempting the classical mammary reconstitution experiment with DDC-4-infected epithelial cells. We therefore chose to achieve local overexpression of DDC-4/sFRP-4 by transplanting the more stably expressing infected $30 \mathrm{~F}$ fibroblast cells into the intact epithelial anlage. The phenotypic effect on the developing endogenous epithelium was studied morphologically and by in situ detection of apoptotic cell death (TUNEL). Transplantation of $30 \mathrm{~F}$ mammary fibroblastic cells expressing DDC-4/sFRP-4 in the pubertal mammary gland resulted in local, abnormal, dysplastic development of the endogenous epithelium (Figure 2b). Terminal end-buds formed numerous, extremely small bud-like immature alveolar protrusions, but failed to extend normally through the fatty tissue (data not shown). Moreover, the TUNEL assays revealed local apoptotic cell death in the developing mammary epithelium in regions of implanted, DDC/sFRP-4-expressing 30F cells, but not in regions transplanted with normal $30 \mathrm{~F}$ cells. In Figure $2 \mathrm{c}$, two TUNEL-positive cells are apparent, as against 26 positive cells shown in the field of Figure $2 \mathrm{~d}$. 

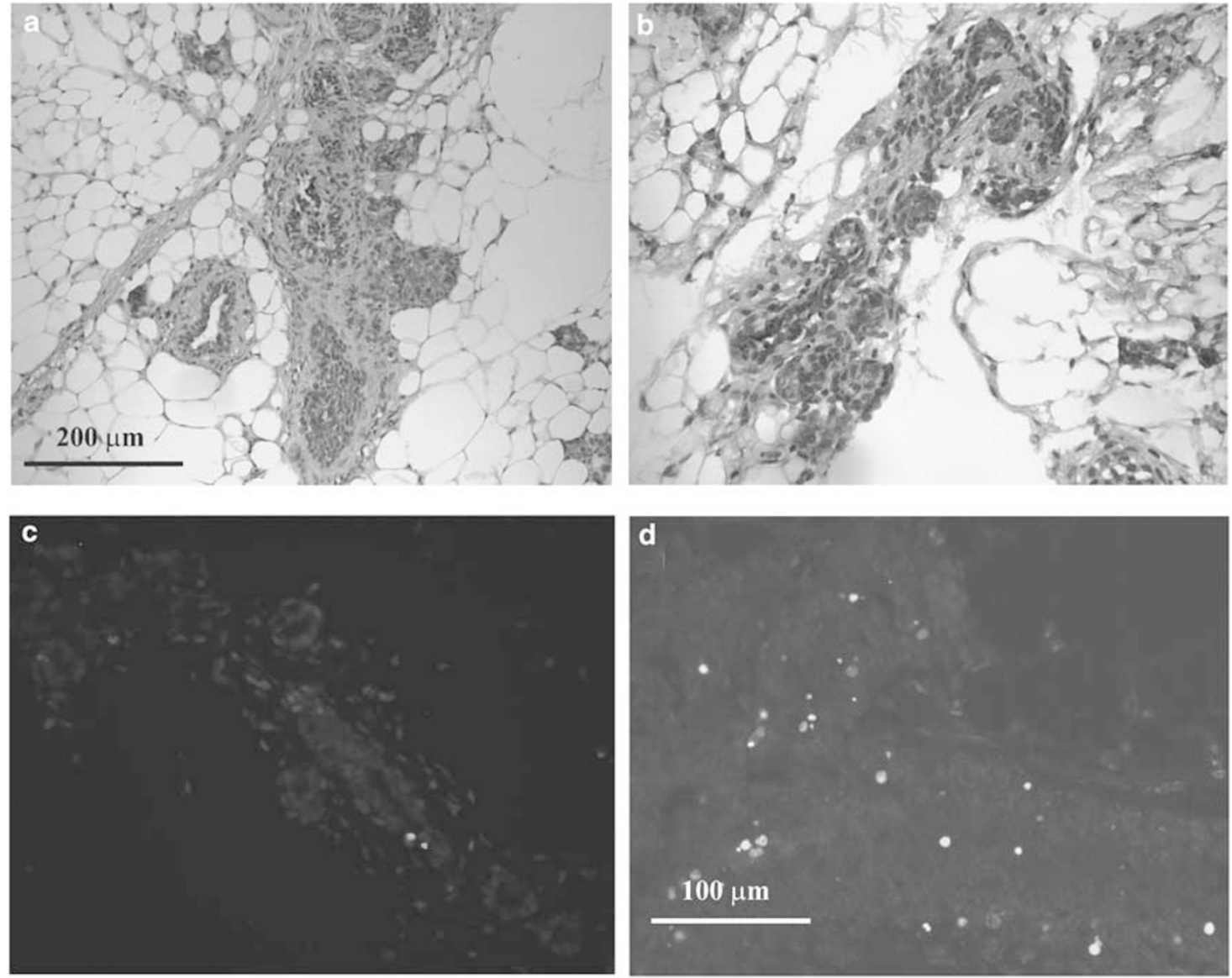

Figure 2 Phenotypic consequences following transplantation of DDC-4-expressing line 30F fibroblastoid cells are illustrated with micrographs of histological sections $(\mathbf{a}-\mathbf{d})$. Infected $30 \mathrm{~F}$ cells were transplanted into the intact mammary gland of pubertal BALB/c mice. Cells infected with retroviral vectors lacking the insert (a, c) are contrasted with cells receiving the DDC-4-pBabe $\mathrm{puro}^{\text {p }}(\mathbf{b}, \mathbf{d})$. Hematoxylin and eosin staining is shown in $\mathbf{a}$ and $\mathbf{b}$. TUNEL detection of DNA fragmentation employing BODIPY-labeled dUTP is presented in $\mathbf{c}$ and $\mathbf{d}$. The magnifications for $\mathbf{a}, \mathbf{b}$ and $\mathbf{c}$ indicated by the bar in $\mathbf{a} ; \mathbf{d}$ was taken at a higher magnification as indicated

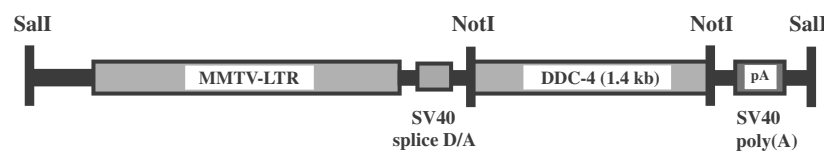

Figure 3 Schematic representation of the MMTV-LTR-DDC-4 transgene

\section{Establishment of DDC-4/sFRP-4 transgenic mice}

The mouse mammary tumor virus (MMTV)-LTR has been extensively employed as a promoter in transgenic constructs aiming to achieve tissue-specific mammary expression in a developmental window between late pregnancy and lactation. ${ }^{18}$ This time period was particularly appropriate for our study, in that early lactation is a time of differentiated function in the mammary gland; neither proliferation nor apoptosis present themselves as a significant background to interfere with the recognition of a DDC-4/sFRP-4-induced phenotype.

The transgene construct used to produce the transgenic animals is schematically shown in Figure 3 . Eight positive transgenic founders were identified based on PCR-DNA analysis; however, only two proved to be $D D C-4 / S F R P-4$ expressing lines, 718 and 721 . Northern blots were performed with RNA from the mammary gland obtained at different reproductive stages. As expected for the MMTV-LTR promoter, animals of line 718 showed maximal $D D C-4 / S F R P-4$ expression in mammary glands at early lactation (Figure 4a). Expression at puberty was totally negative, and, interestingly, transgene expression was not observed during pregnancy before the day 18 (data not shown). In contrast, line 721 exhibited highest levels of $D D C-4 / s F R P-4$ expression in later lactation, while it was undetectable at late pregnancy (Figure 4a). Strange et al. ${ }^{1}$ and Guenette et al. ${ }^{19}$ have established sulfated glycoprotein-2 (SGP-2; clusterin) as an excellent marker for apoptosis in the mammary gland and, thus, its expression was investigated in the DDC-4/sFRP-4 transgenic animals by probing the same blots as discussed above. Interestingly, the levels of SGP-2 expression observed correlated well with transgene expression (Figure 4a). Western blot analyses of protein extracts from line 718 mammary glands at different stages of development showed that DDC-4/sFRP-4 protein expression was consistent with the RNA levels (Figure 4b).

Both lines expressed the transgene most highly in the largest fourth inguinal mammary gland and less in the second. Tissue specificity was only partial; as previously reported, ${ }^{20}$ 


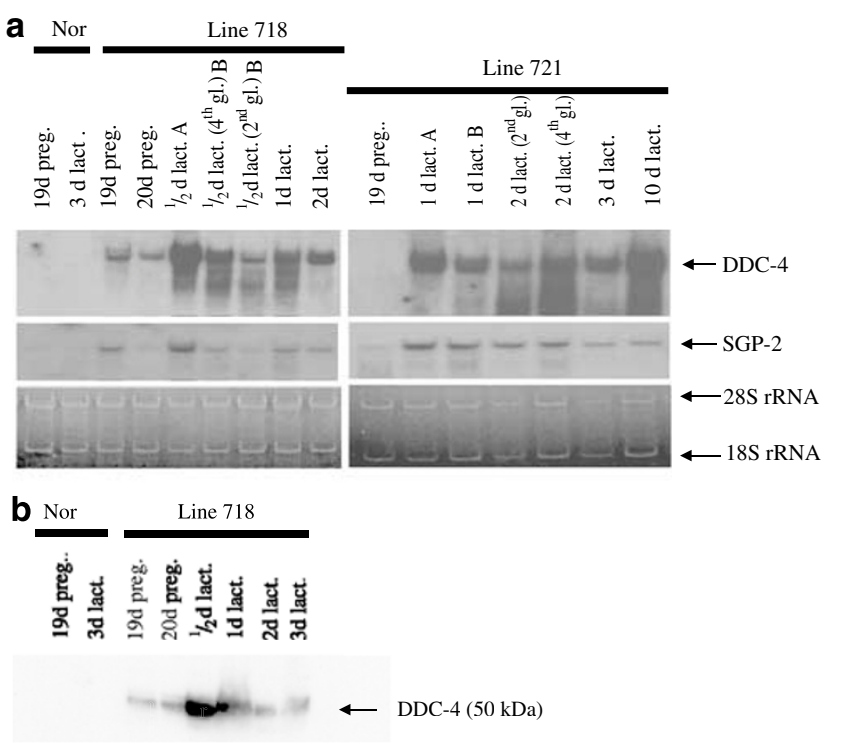

Figure 4 (a) Northern blot analysis of DDC-4/sFRP-4 expression in line 718 and line 721 transgenic mice. RNA was isolated from 19-day pregnant (19d preg.) and 3-day lactating (3d lact.) normal C57BL/6 mice and from the transgenic lines at different times: 19-day pregnant (19d preg.), 20-day pregnant (20d preg.), lactating one-half day, mouse $A(1 / 2 \mathrm{~d}$ lact. A), and mouse $B(1 / 2 d$ lact. B), 1 day (1d lact.), 2 days (2d lact.), 3 days (3d lact.) and 10 days (10d lact.). Standard was to sample the fourth mammary gland; two examples are presented, however, comparing the fourth (4th gl.) and second mammary glands (2nd $\mathrm{gl})$. The blot was probed successively with $D D C-4$, and with sulfated glycoprotein-2 (SGP-2). As loading control, the ribosomal RNA bands in an acridine-orange-stained gel are presented. (b) Western blot analysis of DDC-4/ sFRP-4 expression in line 718 at various stages of mammary gland development

Table 1 Young-rearing characteristics of transgenic lines 718 and 721 in comparison with normal C57BL/6 mice

\begin{tabular}{lcc}
\hline Animals & $\begin{array}{c}\text { Litter size } \\
\text { (no. of litters) }\end{array}$ & $\begin{array}{c}\text { Mean progeny weight } \\
\text { at 7 days of age } \mathbf{( g )}\end{array}$ \\
\hline Line 718 & $4.8(5)$ & $2.8 \pm 0.2$ \\
Line 721 & $6.3(3)$ & $3.4 \pm 0.2$ \\
Normal C57BL/6 & $9.7(3)$ & $3.9 \pm 0.2$ \\
\hline
\end{tabular}

All data displayed refer to first litters of heterozygote DDC-4/sFRP-4-expressing mothers. The indicated litter sizes are averaged over the number of litters indicated

the salivary gland was also an important site of expression in lactating animals (data not shown). Other organs tested were kidney, liver, brain, skin, and testis, which were uniformly negative (data not shown).

\section{The phenotype of transgenic DDC-4/sFRP-4- expressing animals}

A comparison of lines 718 and 721 with negative controls in terms of young-rearing characteristics revealed that both lines have reduced litter sizes as well as reduced mean progeny weights at 7 days of age (Table 1). Young from the 718 line fostered from the first day after birth by control mothers showed normal weight gain at 7 days of age (data not shown). This indicates that the DDC-4/sFRP-4 transgenic animals exhibit a lactational defect, at least at the beginning of the lactating period.

In order to document the phenotype of DDC-4/sFRP-4 overexpression in the mammary gland, we examined the tissue samples with a variety of histological procedures. Figure $5 \mathrm{a}$ and $\mathrm{b}$ show the morphology at $12 \mathrm{~h}$ postpartum after hematoxylin and eosin staining of normal and DDC-4-overexpressing mammary gland sections. Noticeably abnormal were cyst-like structures present occasionally in DDC-4/ sFRP-4 transgenic glands, but generally, little evidence of abnormality was apparent. Infiltration by macrophages and eosinophils in the early lactating mammary glands was not elevated.

In situ hybridization using a $D D C-4 / s F R P$-4-specific probe revealed that in early lactation (12 $\mathrm{h}$ after parturition), transgene expression was restricted to the epithelial cells, while fat cells and blood vessels were uniformly negative. In the epithelium, however, transgene expression was not homogenous; strongly positive areas were found beside negative ones (Figure 5d-f). Immunohistochemistry with affinity purified DDC-4-specific antibodies showed protein expression in agreement with the in situ hybridization results (Figure $5 \mathrm{~g}$ and $\mathrm{h}$ ).

We used the TUNEL assay to investigate in situ apoptotic cell death. In contrast to normal control tissues (Figure 6a and b) that showed very few apoptotic cells, DNA fragmentation in cells of the alveolar lumenal epithelium were detected in large numbers in the alveoli of transgenic animals at late pregnancy (Figure 6c) and $12 \mathrm{~h}$ postpartum (Figure 6d). Cell death was also evident by the appearance of apoptotic bodies judged on the basis of nuclear size and shape (Figure 6c). A yellow-fluorescing artefact exhibited by erythrocytes, hemosiderin, and accumulations of debris must be ignored.

The DDC-4/sFRP-4-positive mammary glands continued to secrete milk, sufficient to nourish some of the young. Thus, it seemed likely that dying cells were being replaced with newly differentiated cells. In order to address this question, we have investigated cell proliferation using BrdU labeling during a 3-h in vivo treatment prior to killing. Indeed, an elevated proportion of BrdU-positive cells was observed in sections of line 718 mammary glands at day 2 of lactation (Figure 6f) as compared to the normal control (Figure 6e).

Caspases are a family of proteases whose activation is thought to represent an irreversible event in the apoptotic process. Caspase-3 has been shown to be ultimately involved in mammary epithelial involution. ${ }^{21}$ In order to obtain some insight into the relative expression of DDC-4/sFRP-4 and activated, cleaved caspase-3 as a marker for ongoing apoptosis, serial sections of mammary gland, line 718 , taken $12 \mathrm{~h}$ after parturition, were stained. Serial sections compared staining with anti-cleaved caspase- 3 antibody versus that with anti-DDC-4/sFRP-4 antibody. Along the alveolar and ductal lining of the lumen, only a small fraction of the epithelial cells exhibited moderately strong cleaved caspase-3 staining, although a much larger fraction were already DDC-4/sFRP4 positive. Thus, either the cleaved-caspase-3 expressing fraction has a shorter half-life in the tissue, or the majority of 

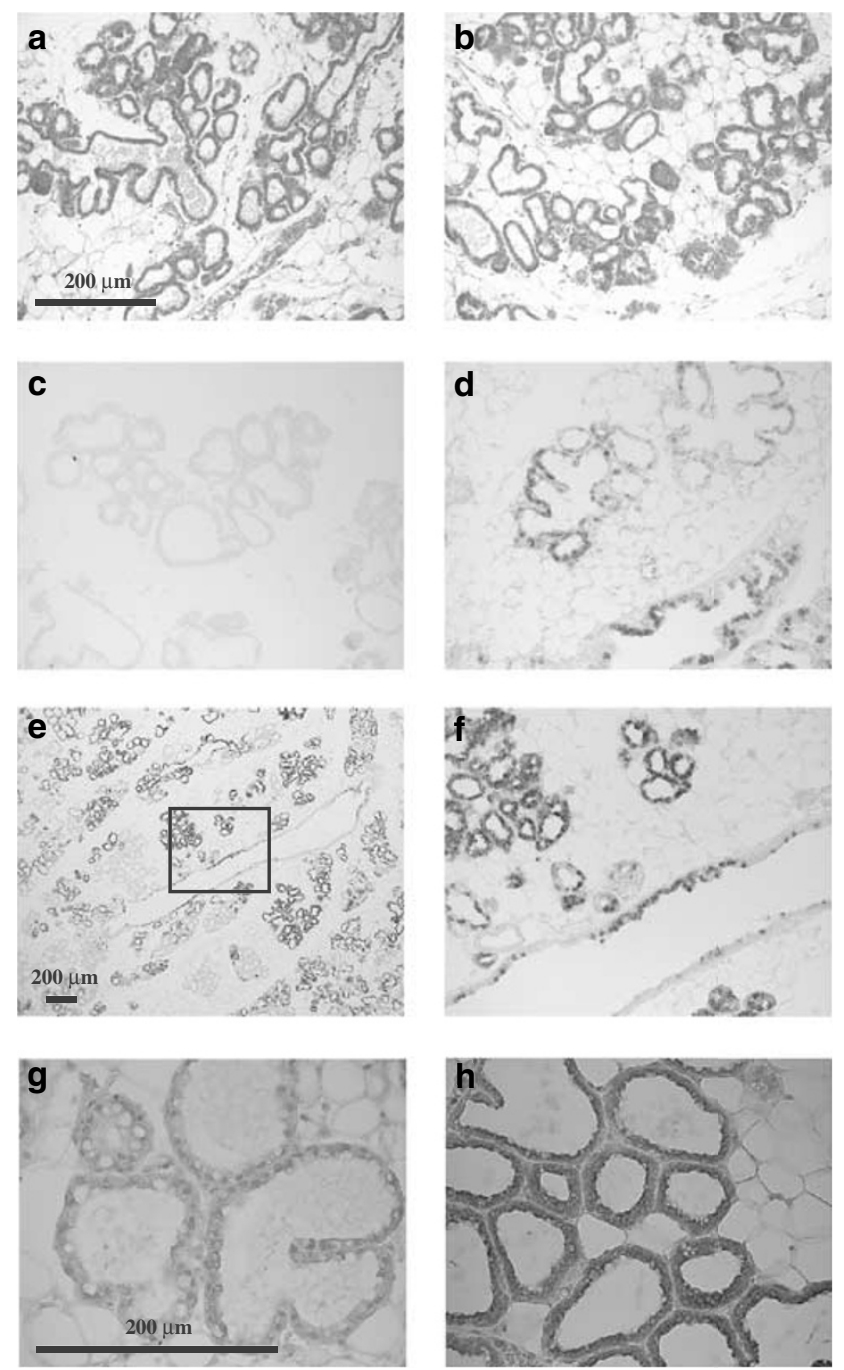

Figure 5 Histological appearance of DDC-4/sFRP-4 transgenic mammary glands. Hematoxylin and eosin staining of mammary glands $12 \mathrm{~h}$ postpartum from normal (a) and line 718 mice (b). (c-f) In situ hybridization with a $D D C-4 /$ $s F R P-4$ probes (c, sense and $\mathbf{d}-\mathbf{f}$, antisense) on transgenic mammary glands $12 \mathrm{~h}$ after parturition. The immunohistochemical detection of DDC-4/sFRP-4 in control C57BL/6 mice $(\mathbf{g})$ and transgenic mice at 2 days of lactation $(\mathbf{h})$ is shown. Note that essentially all lumenal epithelial cells express DDC-4/sFRP-4 at this time. Magnifications are indicated by the bars in a (for $\mathbf{a}-\mathbf{d}, \mathbf{f}$ ), in $\mathbf{e}$ at low magnification (expanded in $\mathbf{f}$ ) and in $\mathbf{g}$ (for $\mathbf{g}$ and $\mathbf{h}$ )

the DDC-4/sFRP-4-positive cells fail to develop further to frank apoptosis. The residual milk secretion in the gland, allowing survival of half the progeny, speaks for the latter.

\section{Caspase-3 enzymatic activity in mammary tissues from normal and transgenic mice}

As demonstrated above, transgenic mammary glands show evidence of apoptosis in a time window between the last days of pregnancy and day 2 of lactation. A fluorescence assay for caspase-3 activity was performed in vitro to confirm the results
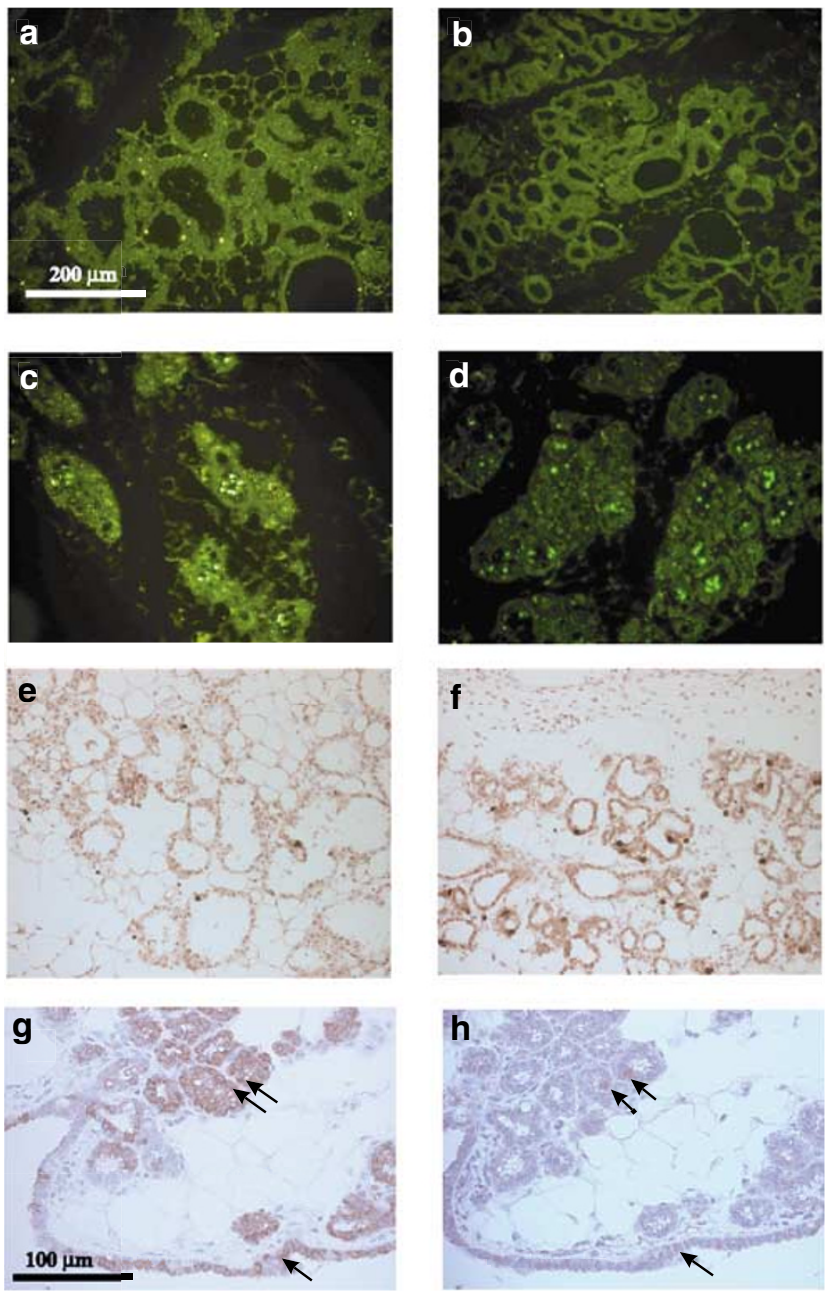

Figure 6 TUNEL reactions, used to document programmed cell death, are shown in (a)-(d). The TUNEL reaction was performed with fluorescent BODIPYdUTP substrate on mammary gland sections from 20-day pregnant mice ((a) and (c)) and with mice $12 \mathrm{~h}$ after parturition ((b) and (d)). Mammary glands of C57BL/ 6 control mice ((a) and (b)) and transgenic line 718 mice ((c) and (d)). An in vivo BrdU labeling assay for cell proliferation was performed $3 \mathrm{~h}$ before killing. Immunohistochemical detection of incorporated BrdU is shown for normal C57/ bl6 in (e) and in (f) for line 718 transgenic mammary glands at 2 days of lactation. Serial sections of mammary gland, line 718 , taken at $12 \mathrm{~h}$ after parturition, are shown for comparison after staining with anti-DDC-4/sFRP-4 (g) or with antiactivated (cleaved) caspase-3 (Cell Signaling Technologies) (h) affinity-purified antibodies. The arrows indicate cells in the same locations. Such comparisons provide suggestive evidence that only a minortity of the lumenal epithelial cells exhibit a strong cleaved-caspase-3 positive staining, although many alveolar cells are already DDC-4/sFRP-4 positive. Magnifications are indicated by the bars in a (for $\mathbf{a}-\mathbf{f}$ ) and in $\mathbf{g}$ (for $\mathbf{g}$ and $\mathbf{h}$ )

obtained from the TUNEL reaction, the cleaved caspase-3 immunohistochemistry and the Northern blots for SGP-2 expression, which together had indicated an onset of apoptosis congruent with transgene expression. The control animals were negative for activated capase-3 at lactation and as expected exhibited caspase- 3 activation already 1 day after forced weaning (Figure 7). In contrast, a three-fold induction of activated caspase- 3 could be detected in mammary glands of line 718 transgenic animals already at day 19 of pregnancy. The peak caspase-3 activity 


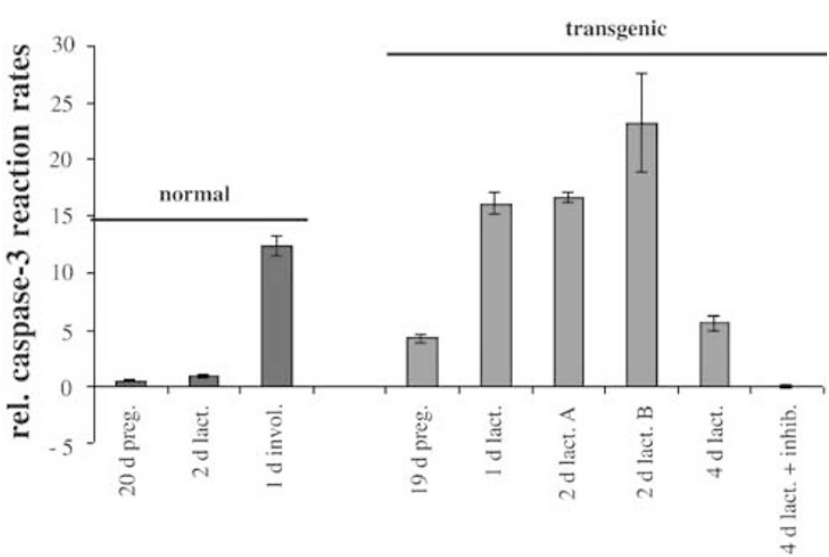

Figure 7 Schematic representation of caspase-3 activites as measured with the Z-DEVD-amino-4-methyl coumarin (AMC) substrate in a fluorescence assay. Normal C57BL/6 control mice (normal) were compared with line 718 transgenic animals at different days (d) of pregnancy (preg.), lactation (lact.), or involution (invol.). For the transgenic mammary glands at 2-day lactation, two separate animals ( $A$ and $B$ ) were studied. A reaction was performed with and without the reversible aldehyde inhibitor Ac-DEVD-CHO specific for caspase-3, in order to confirm specificity (4d lact, 4d lact+inhib.). Bars represent mean values; standard deviations are indicated

was detected in transgenic mammary glands at 1-2 days of lactation and declined thereafter (Figure 7). Thus, the appearance of apoptotic cells detected by the TUNEL assay is paralleled by the activation of caspase-3, indicating that unscheduled expression of DDC-4/sFRP-4 induces programmed cell death in the mammary epithelium.

\section{Decline in PKB/Akt phosphorylation precedes onset of apoptosis and parallels loss of phosphorylation in GSK-3 $\beta$, BAD, and Forkhead}

The question remains why the upregulation of DDC-4/sFRP-4 leads to apoptosis. From its predicted function as a secreted Frizzled competitor, DDC-4/sFRP-4 can be anticipated to block Wnt-Frizzled signaling, in this case probably by competing for available Wnt-4. From the work of several groups, one can speculate that Wnt-4 is the probable target for DDC-4/sFRP-4, ${ }^{17,22,23}$ but the link from Wnt signaling to a survival pathway remains somewhat elusive. Thus, we performed the experiments shown in Figure 8, which presents the results of a PKB/Akt protein kinase assay and of Western blot experiments, together documenting a major survival pathway, the PI-3 kinase (PI3 K), and PKB/Akt pathway, through which many growth factors maintain cell survival. The study was performed within a narrow time window in which mammary glands contain a maximal proportion of lumenal epithelial cells (from 19 days pregnancy to 2 days of involution). Samples were normalized to a constant amount of PKB/Akt protein as detected with Western blot, then parallel blots were probed with phosphorylation-specific, affinitypurified antibodies for PKB/Akt itself, for GSK-3 $\beta$, for the proapoptotic BAD, which is held in the inactive form through phosphorylation, and for the transcription factor Forkhead. The results in Figure 8 indicate that $\mathrm{PKB} / \mathrm{Akt}$ kinase activity is greatly reduced in line 718 samples, taken both in pregnancy

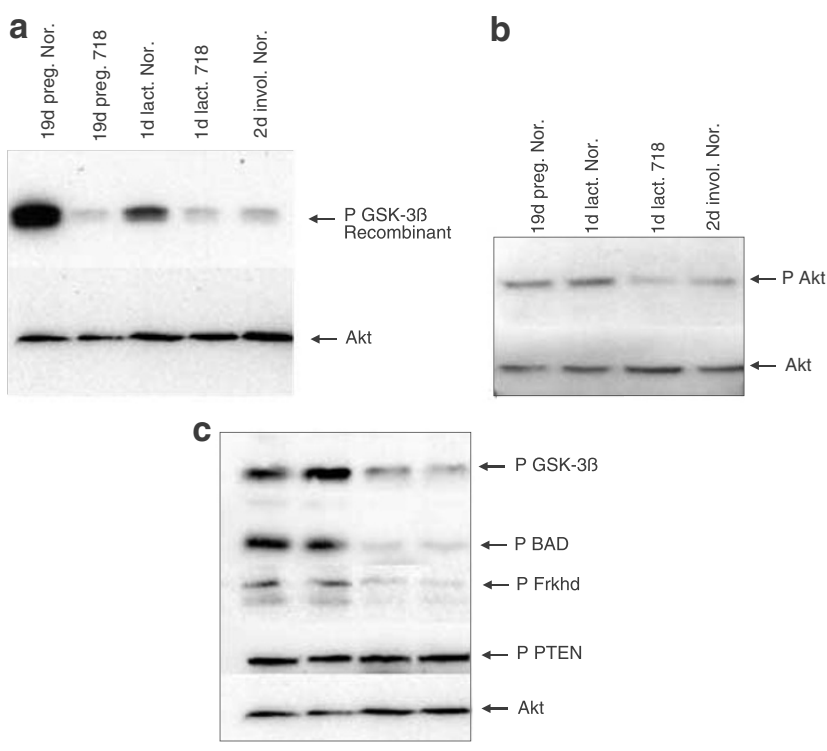

Figure 8 (a) PKB/Akt kinase activity was measured on tissue samples of mammary glands obtained from normal C57BL/6 mice at 19 days of pregnancy (19d preg. Nor.), lactation 1 day (1d lact. Nor) and 2 days of involution after forced weaning ( $2 \mathrm{~d}$ invol. Nor.) and from line 718 mice at 19 days pregnancy ( $19 \mathrm{~d}$ preg. 718 ) and 1 day of lactation (1d lact. 718). Tissue samples were lyzed (see Materials and methods), immunoprecipitated with immobilized anti-PKB/Akt antibody and subjected to a kinase reaction in the presence of recombinant GSK$3 \beta$ and ATP. PAGE and electroblotting were performed and Western blots analyzed with antibodies specific for phospho-GSK-3 $\beta$ and PKB/Akt. The latter was a control for equal loading. (b) The phosphorylation of PKB/Akt was analyzed by PAGE followed by immunoblotting of several mammary gland tissue samples from normal C57BL/6 and line 718 transgenic mice. These samples had been rapidly lysed in sodium dodecyl sulfate-containing sample buffer. Specific antibody reactive with phospho PKB/Akt (Ser-473) demonstrated the activated fraction, while affinity-purified anti-PKB/Akt antibody applied to a parallel blot indicated the equivalence of loading. (c) Several substrates of PKB/Akt were lysed, separated on PAGE and analyzed in Western blots utilizing phosphospecific, affinity-purified from Cell Signaling Technologies. Arrows indicate phospho-GSK-3 $\beta$, phospho-BAD (Ser-136), phospho forkhead (Ser-256), phospho PTEN (Ser-380) as well as the control for equivalence of loading, anti-PKB/Akt

and in lacation. Likewise, PKB/Akt phoshorylation is reduced in control normal tissues at 2 days of involution and in the line 718 transgenic 1 day lactation sample. With the onset of apoptosis in the involuting mammary glands of the normal control mice, GSK-3 $\beta$ phosphorylation, and most significantly BAD and Forkhead phosphorylation is decreased. Since the phosphorylated form of BAD is known to be inactive, the release of the proapoptotic form seems likely to have an impact in the initiation of apoptosis. While the normalization was to the amount of total PKB/Akt detected in the blots, it is interesting that PTEN phosphorylation, an activity upstream of the PKB/Akt, impacting mainly on $\mathrm{PI} 3 \mathrm{~K}$ itself, exhibited essentially no effect from either the DDC-4/sFRP-4 overexpression in line 718, or from the onset of involution in the normal controls.

\section{Discussion}

The defining signals responsible for the transition from lactation to involution in the mammary gland are still unknown. 
While procedures that induce a local involution in sealed mammary glands have shown that regulation by systemic hormones cannot be the main determining factor in the onset of involution, ${ }^{24}$ there remain several other hypotheses. For example, transforming growth factor $\beta 3$ has been proposed. ${ }^{25}$ Most hypotheses, however, focus on the loss of survival signals. Extracellular matrix-integrin interactions presumably represent an important link between adhesion and the events of apoptosis. ${ }^{26}$ In this context, one can speculate that the induction of tissue remodeling proteases capable of degrading basement membrane might be an early trigger for programmed cell death. ${ }^{27}$ Recent work, however, tends to show that the earliest events of apoptosis occur before detectable changes in extracellular matrix or cognate integrin receptors can be detected. ${ }^{28}$ Other survival signals of importance are the insulin-like growth factors (IGFs), whose function can be blocked by IGF-binding proteins (IGFBP). For example, IGFBP-5 is produced very early at the onset of involution; hence, it could well be a relevant mediator of apoptosis in mammary involution. ${ }^{29}$ However, for every mechanism thus far proposed, just as for the role of DDC-4/ sFRP-4 described above, it remains to question as to what sensing system triggers the involution program. Quite possibly, engorgement and physical strain communicate the end of lactation and beginning of involution, presumably via changes in gene expression. ${ }^{30}$

The importance of the Wnt/Frizzled signaling pathway in mammary development has emerged only very gradually. ${ }^{31}$ Wnt-1 was early recognized as the oncogene responsible for many of the MMTV-induced neoplasms. Wnt-1 was overexpressed inappropriately in the mammary gland as a result of a downstream promotion caused by the nearly random integration of the MMTV. Since Wnt-1 is not normally expressed in the mammary gland at any developmental stage and since it can apparently interfere with the action of some other Wnts on its receptor, a potential for disregulation is realized, the consequence being a mammary tumor.

DDC-4 belongs to the sFRP family, recently recognized as regulators of the Wnt signaling system. ${ }^{12,13,32}$ Their role as extracellular competitors for Wnt ligands is to reduce the probability that Frizzled receptors are activated, that is, to block the Wnt/Frizzled signaling pathway. Although both the ligand with which DDC-4/sFRP-4 binds and the Frizzled receptor that it blocks are still unknown, it was to be anticipated that like the expression of Wnt-1, inappropriate DDC-4/sFRP-4 expression would probably disturb Wnt/Frizzled regulation in the tissue. We hypothesized that a necessary survival signal may be blocked, leading to the apoptotic pathway.

The approaches employed here to show the phenotypic consequences of ectopic DDC-4/sFRP-4 expression have not previously been used in combination. The transgenic mammary gland approach traditionally relies on epithelial reconstitution to demonstrate a phenotypic effect, ${ }^{17,22}$ The effects reported in the past have been hyperplasia and tumor induction, and apparently did not suffer from the declining expression that is probably unavoidable with this approach. Our experiments differ and illustrate that transplantation of cells secreting a soluble effector can generate a local phenotype that is readily observable acting on the endogenous, normal epithelium. Unfortunately, our experience was that ex vivo infected cells, even primary cells, which should exhibit a normal phenotype, take on characteristics during their brief stay in culture inducing a reactive tissue response. This effect is quite apparent in a system that lacks any additional proliferative stimulus. With our second approach to study DDC-4/sFRP-4 overexpression, the transgenic mouse model, we could avoid such immune reactions.

Transgenic animals have been established, which overexpress a variety of oncogenic, growth-inducing ${ }^{15,33}$ or antiapoptotic $^{34}$ genes. Unusual in our study is the overexpression of a presumptively proapoptotic gene product, DDC-4/sFRP-4. Such an experiment suffers from several problems, most notably the risk that an apoptotic phenotype may not be sufficiently synchronous to allow dying cells to be observed before their removal by the action of phagocytes. In fact, the DDC-4/sFRP-4-overexpressing transgenic mice illustrate this problem in early lactation. It is noticeable, that while maximal apoptosis measured by TUNEL reaction is observed within $12 \mathrm{~h}$ after parturition, the peak activity of caspase-3 was detected somewhat later and remained elevated longer.

The significance of the observed apoptotic potential of DDC-4/sFRP-4 lies in the congruence between the observations made on its expression in normal physiological apoptosis in several tissues and in mammary glands of transgenic DDC-4/sFRP-4 overexpressors. In essence, these experiments serve as a proof of principle. Where previously an association of DDC-4/sFRP-4 upregulation with apoptosis was recognized, we can now speak of causation, at least in a limited sense.

A probable mechanism by which DDC-4/sFRP-4 causes cell death is by abrogating PI3 K-PKB/Akt survival signaling: $\mathrm{PKB} / \mathrm{Akt}$ binds to $\mathrm{PI} 3 \mathrm{~K}$-generated phospholipids and translocates from the cytoplasm to the inner surface of the plasma membrane, where PI3 K-generated 3'-phosphorylated phospholipids reside. Relocalization to the plasma membrane brings $\mathrm{PKB} / \mathrm{Akt}$ in proximity to regulatory kinases that phosphorylate and activate PKB/Akt. ${ }^{35}$ Four sites (Ser-124, Thr-308, Thr-450, and Ser-473) were identified on Akt1 that can be phosphorylated in vivo. ${ }^{36}$ However, PKB/Akt activity appears to depend on phosphorylation of Thr-308 and Ser473; Ser-124 and Thr-473 seem to be basally phosphorylated. $^{35}$ Thr-308, in the presence of $\mathrm{PI} 3,4,5 \mathrm{P}$, becomes phosphorylated by 3-phosphoinositide-dependent protein kinases (PDKs). ${ }^{35,37,38}$ Ser-473 may become phosphorylated through a complex consisting of PDK-1 and PRK-2 (protein kinase C-related kinase-2), and by integrin-linked kinase (ILK), a serine/threonine kinase that interacts with the cytoplasmic tail of integrin $\beta$ subunits. ${ }^{35}$ Activation of $\mathrm{PKB} /$ Akt results in the phosphorylation of, among others, glycogen synthase kinase 3 (GSK3), the proapoptotic Bcl-2 family member BAD, caspase- 9 , and Forkhead transcription factors. ${ }^{35,39,40}$ Note that, although BAD functions as a proapoptotic molecule, its phospho-form represents an inactive state not inducing cell death. ${ }^{39}$

Interestingly, inactivation of GSK-3 $\beta$ through phosphorylation may result in nuclear accumulation of $\beta$-catenin ${ }^{40}$ and thereby provides a link, at least in one direction, to the classical Wnt/ $\beta$-catenin pathway. Our data presented here support this view. Being a member of the sFRP family, it is 
probable that DDC-4/sFRP-4 abrogates a Wnt-regulated signal transduction pathway. Since involuting normal mammary glands as well as DDC-4/sFRP-4-overexpressing transgenic glands at lactation showed reduced levels of both PKB/Akt kinase activity, and reduced GSK-3 $\beta$, BAD and Forkhead phosphorylation (Figure 8), we conclude that the observed correlation between DDC-4/sFRP-4 expression and increased rates of apoptosis is because of an inactivation of a $\mathrm{PKB} /$ Akt-dependent survival pathway.

Although our observations can best be explained by functional links between Wnt signaling and the PI3 K-PKB/ Akt pathway, we do not know at which biochemical level the crosstalk between the two signaling systems occurs. GSK-3 $\beta$ may be the point of convergence. GSK-3 $\beta$ is recognized as an important modulator of apoptosis. GSK-3 $\beta$, for instance, downregulates the activities of several transcription factors that are critical promoters of cell survival, such as heat shock factor-1 (HSF-1) and cyclic AMP response element binding protein (CREB). ${ }^{41}$ Furthermore, caspase-3 activation induced by inhibition of mitochondrial complex I has been shown to be facilitated by GSK-3 $\beta .^{42}$ Since both PI3K-PKB/Akt as well as Wnt signaling inhibit GSK-3 $\beta$ activity, one might speculate that a DDC-4/sFRP-4-induced inhibition of the Wnt pathway reactivates GSK-3 $\beta$ and thereby promotes cell death. Recent reports by Song et al. ${ }^{43}$ and Fukumoto et al. ${ }^{44}$ indicate that the Wnt pathway can phosphorylate and activate PK-B/Akt via another intermediate player, dishevelled. Their results differ in the involvement of GSK-3 $\beta$ in this crosstalk. Significant in the context of our results, however, is that Fukumoto et al. ${ }^{44}$ show not only that downregulation of the PI3 K and PKB/Akt pathway parallels a reduced GSK-3 $\beta$ phosphorylation, thus inhibiting Wnt signaling, but also, most interestingly, that Wnt signaling through dishevelled is able to activate PKB/Akt. Thus, the crosstalk is not just one way, it is 'hand-shaking'.

In summary, we have described the role of DDC-4/sFRP-4 in inducing apoptosis. Late pregnant and lactating mammary glands of DDC-4/sFRP-4-overexpressing transgenic mice showed pronounced cell death as determined by Northern blot analysis for sulfated glycoprotein-2, immunohistochemistry for cleaved caspase-3, as well as in TUNEL and caspase-3 assays. We have previously shown that $D D C-4 / s F R P-4$ was upregulated in various tissues undergoing physiological apoptosis. $^{3,4,45}$ The new data show that DDC-4/sFRP-4 expression is a stimulus rather than a consequence of the apoptotic program in the mammary gland. Since DDC-4 is an sFRP and thus thought to sequester Wnt ligands, we propose a role for DDC-4/sFRP-4 in abrogating a Wnt-regulated survival pathway, the latter possibly signaling via PKB/Akt. Since PI3 K and PKB/Akt appears to delay the onset of p53mediated, transcriptionally dependent apoptosis, ${ }^{46}$ it would be interesting to explore the potential of DDC-4/sFRP-4 in overriding the p53-associated cell death inhibition mechanism active in many human tumors.

\section{Materials and Methods}

\section{Construction of the DDC-4/sFRP-4 retroviral vector}

The DDC-4/sFRP-4 CDNA, containing the entire coding sequence, was employed as template for the retroviral construct. ${ }^{4}$ Because of the absence of suitable restriction enzyme sites that would allow the coding information to be cloned into the $\mathrm{pBabe}{ }^{\text {puro }}$ vector without extensive $5^{\prime}$ and $3^{\prime}$ untranslated regions, we used PCR to obtain a subfragment spanning the coding sequence associated with short (20-30 bp) $5^{\prime}$ and $3^{\prime}$ untranslated regions. The primers were constructed to contain restriction enzyme sites near their $5^{\prime}$ termini, BamH1 for the sense, and EcoRI for the antisense primers. The resulting PCR product was restricted, purified and cloned into the respective sites of the $\mathrm{PBABE}^{\text {puro }}$ murine leukemia virus vector. ${ }^{47}$ Preparation of packaged virus was performed in BOSC cells derived from the human 293 kidney tumor line. ${ }^{16}$

\section{Culture of clone 31D mouse mammary epithelial cells, clone 30F mammary fibroblastoid cells and primary mammary fibroblasts}

Epithelial 31D and fibroblast-like 30F mammary cell lines, capable of differentiation in vitro, were derived from BALB/c mid-pregnant mammary glands in our laboratory. ${ }^{48,49}$ Monolayer cultures maintained in medium with $10 \%$ fetal calf serum supplemented with insulin $(5 \mu \mathrm{g} / \mathrm{ml})$ were infected with the $\mathrm{pBabe} \mathrm{puro}^{\text {puro }}$ retroviral constructs, with and without the $D D C-4 / s F R P-4$ insert. Selection with puromycin at $25 \mu \mathrm{g} / \mathrm{ml}$ was begun after $24 \mathrm{~h}$ and maintained for at least $96 \mathrm{~h}$. Cultures were propagated for up to 10 weeks, with reselection at intervals. Samples for RNA isolation were taken weekly.

Primary mammary fibroblast cells were prepared from mid-pregnant $\mathrm{BALB} / \mathrm{c}$ mice. Mammary glands were minced on dry cell culture plates to fragments $<1 \mathrm{~mm}^{3}$. The fragments were transferred to new culture dishes and allowed to dry for $5 \mathrm{~min}$ at room temperature after which Eagle's Dulbecco-modified medium (EDM) containing 10\% fetal calf serum was added. After 4-5 days, the dish was confluent with fibroblasts growing out of the fragments. The primary fibroblast cultures were trypsinized briefly, trypsin removed and the cells resuspended in EDM containing $10 \%$ fetal calf serum. The fragments were allowed to settle out, and the suspension of single cells was centrifuged at $1000 \times g$ for $3 \mathrm{~min}$. The pellet was resuspended in EDM with $1 \%$ fetal calf serum, polybrene (final concentration $8 \mu \mathrm{g} / \mathrm{ml}$ ) and the virus stock suspension (multiplicity of infection approximately 0.5 ). Cultures were exposed for $60 \mathrm{~min}$ at room temperature to the virus. Thereafter, the suspension was again pelleted, and finally the cells plated in $5 \%$ fetal calf serum containing EDM. After $24 \mathrm{~h}$, puromycin (final concentration $25 \mu \mathrm{g} / \mathrm{ml}$ ) selection was begun. After selection for 4 days, puromycin was removed. An approximately three-fold expansion of the fibroblast culture was achieved by 7 days.

\section{Transplantation of ex vivo-infected cells into BALB/c mice}

Cultures of cells were trypsinized, resuspended in EDM containing 10\% fetal calf serum briefly to inhibit the protease and then pelleted twice successively in cold EDM without serum. Dense suspensions of approximately $4-6 \times 10^{6}$ cells $/ \mathrm{ml}$ were prepared and $20-40 \mu$ l amounts transplanted into pockets made in the mammary fat pads of the fourth glands prepared with fine forceps just medial from the major, large mammary lymph node. BALB/c mice were either 5-week-old pubertal females, or mature females at the 17 days of pregnancy. Mice were anesthetized using pentabarbitol, and the wound was sutured carefully to close tightly. For studies of puberty, mice were killed after 1 week; transplantation into pregnant mice was analyzed 6 days after implantation, in the lactating state 2 days after delivery of normal litters. Mammary glands were examined as whole mounts, or each gland was divided into 
fragments ca. $1.5 \mathrm{~cm}$ long to provide material for both RNA isolation (frozen at $-80^{\circ} \mathrm{C}$ in lysis buffer) and fixation in freshly prepared $4 \%$ formaldehyde solution at $4^{\circ} \mathrm{C}$ for $16 \mathrm{~h}$.

\section{Preparation of rabbit polyclonal, affinity-purified DDC-4/sFRP-4 antibodies}

The DDC-4/SFRP-4 coding sequence was cloned in frame into the appropriate pGEX expression plasmid and the glutathione $S$-transferaseDDC-4 fusion protein expressed in Escherichia coli. The fusion protein was isolated by preparative SDS-PAGE. Rabbits received multiple, intradermal injections of approximately $500 \mu \mathrm{g}$ fusion protein, initially with Freund's complete and thereafter with Freund's incomplete adjuvant. Antibodies were affinity purified by absorption to antigen coupled to Reacti-Gel HW-65F support (Pierce, Rockford, IL, USA). Specific antibody was eluted using $100 \mathrm{mM}$ glycine buffer, pH 2.5 and dialyzed against PBS.

\section{PKB/Akt protein kinase assay, SDS-PAGE, immunoblotting, and antibodies}

Tissue lysates were prepared from rapidly harvested, ice-cold samples lysed with the help of a Polytron in a buffer containing $20 \mathrm{mM}$ Tris $(\mathrm{pH} 7.5)$, $150 \mathrm{mM} \mathrm{NaCl}, 1 \mathrm{mM}$ EDTA, $1 \mathrm{mM}$ EGTA, 1\% Triton X-100, $2.5 \mathrm{mM}$ sodium pyrophosphate, $1 \mathrm{mM} \beta$-glycerophosphate, $1 \mathrm{mM}$ sodium orthovanadate, $1 \mu \mathrm{g} / \mathrm{ml}$ leupeptin, and immediately before lysis, $1 \mathrm{mM}$ PMSF.

The PKB/Akt protein kinase assay employed a kit supplied by Cell Signaling Technology (Beverly, MA, USA). The principle is an immune precipitation using immobilized anti-Akt antibody to recover the enzyme quantitatively, followed by a reaction at $30^{\circ} \mathrm{C}$ in the presence of a recombinant fusion protein with GSK-3 peptide substrate and ATP. The phosphorylated product is detected in a Western blot using phospho-GSK3-specific antibody.

Conventional vertical SDS-PAGE was performed with $11 \%$ acrylamidebis-acrylamide according to the method of Laemmli. ${ }^{50}$ Immunoblotting onto nitrocellulose filters was accomplished with a semidry transfer procedure, followed by blocking of the membrane with $4 \%$ nonfat dried milk for 60 min in Tris-buffered saline (TBS: $25 \mathrm{mM}$ Tris, pH 7.5, $150 \mathrm{mM}$ sodium chloride).

The rabbit polyclonal anti-DDC-4 antiserum was employed at a dilution of 1:1000. Anti-Akt, anti-phospho-ser473 Akt, anti-phospho-ser9 glycogen synthetase kinase-3 $\beta$ and anti-phospho-ser136 BAD, anti-phosphoser256 Forkhead and anti-phospho-ser380 PTEN were rabbit antipeptide antibodies obtained from Cell Signaling Technology (Beverly, MA, USA). All were used at a final dilution of 1:1000 except anti-phospho-ser136 BAD that was employed at 1:500 dilution. Detection was performed with an antirabbit IgG antibody conjugated with horse radish peroxidase at 1:2000 dilution (Cell Signaling Technology, Beverly, MA) according to the procedures recommended by the supplier. Luminol was employed as the substrate and the chemoluminescent signal was acquired with a Roche Diagnostics (Rotkreuz, Switzerland) Lumi-Imager.

\section{Preparation of MMTV-LTR-DDC-4 construct and establishment of transgenic animals}

The complete coding sequence of the DDC-4/sFRP-4 CDNA was purified, taking advantage of convenient Kpn-I restriction sites. Ligating on Notl adapters (Roche Diagnostics, Rotkreuz, Switzerland) allowed the construction of an MMTV-LTR expression cassette ${ }^{51}$ containing a $1.4 \mathrm{~kb}$ cDNA fragment covering the $1.05 \mathrm{~kb}$ coding sequence of DDC-4/sFRP-4.
Sall digestion was employed to obtain the entire cassette for microinjection into pronuclei of zygotes generated from $\mathrm{F} 1$ hybrid female mice (C57BL/ $6 \times \mathrm{DBA} / 2$ ) mated to $\mathrm{DBA} / 2$ males. Pronuclear injection was prepared at the Animal Facility of the Center for Molecular Biology (University of Heidelberg, Germany). From the resulting offspring, DNA was prepared from tail biopsies and positive founder mice identified by PCR. Eight founder lines were obtained, of which two expressed the transgene in the mammary glands of pregnant or lactating animals.

\section{Isolation of RNA and Northern blotting}

Total RNA was prepared from tissue samples using the guanidiniumthiocyanate extraction method of Chomczynski and Sacchi. ${ }^{52}$ In total, $5 \mu \mathrm{g}$ of total RNA was denatured with glyoxal, electrophoresed on a $1 \%$ agarose gel and blotted to nitrocellulose. Equal loading was controlled by examination of ribosomal RNA bands following staining with acridine orange as previously described. ${ }^{3}$ Probes for hybridization were prepared using the Random Primed Labeling Kit (Roche Diagnostics, Rotkreuz, Switzerland) including ${ }^{32} \mathrm{P}-\mathrm{dCTP}$ (800 Ci/mM; Amersham International, Little Chalfont, England) in the reaction and hybridization was carried out as previously described. ${ }^{3}$

\section{In situ hybridization, immunohistochemical detection of DDC-4/sFRP-4, incorporated BrdU and activated (cleaved) caspase-3}

Fixation, in situ hybridization and immunohistochemical detection was carried out as previously described. ${ }^{45,53}$ The rabbit affinity purified antiDDC-4 serum was used at a dilution of 1:100 on tissue sections after microwave treatment in $50 \mathrm{mM}$ sodium citrate for $5 \mathrm{~min}$ at reduced energy (maximum temperature, $90^{\circ} \mathrm{C}$ ). For BrdU labeling, females were injected I.P. with $0.2 \mathrm{ml}$ of BrdU $(50 \mathrm{mg} / \mathrm{ml})$ in PBS $3 \mathrm{~h}$ prior to killing. Anti-BrdU antibody was obtained from Roche Diagnostics. For the detection of activated (cleaved) caspase-3, an antibody specific for the cleaved caspase-3 (asp175) was obtained from Cell Signaling Technology.

\section{Terminal deoxynucleotidyl transferase-mediated dUTP nick end-labeling (TUNEL)}

The TUNEL reaction was performed as previously described ${ }^{45}$ using either BODIPY-dUTP visualized directly in the fluorescence microscope (Molecular Probes, Eugene, OR, USA) or digoxigenin-11 dUTP detected with anti-digoxigenin Fab antibodies conjugated to alkaline phosphatase (Roche Diagnostics, Rotkreuz, Switzerland). Fixation was exactly as for in situ hybridization. For the TUNEL, optimization of proteinase $\mathrm{K}$ treatment proved very critical and was carried out with $5 \mu \mathrm{g} / \mathrm{ml}$ proteinease $\mathrm{K}$ in Tris $20 \mathrm{mM}, \mathrm{pH} 7.8$, at $30^{\circ} \mathrm{C}$ for $15 \mathrm{~min}$.

\section{Fluorescence assay for caspase-3 activity}

Numerous small tissue samples $(50 \mathrm{mg}$ ) were obtained from each mammary gland and frozen at $-80^{\circ} \mathrm{C}$. Lysates were prepared in $1 \%$ Triton $\mathrm{X}-100$ (PBS) and were sonicated $2 \times 30 \mathrm{~s}$ on ice with a $5 \mathrm{~mm}$ probe sonifier set to $50 \mathrm{~W}$. Following centrifugation at $4^{\circ} \mathrm{C}$ and $50000 \times \mathrm{g}$, $100 \mu \mathrm{g}$ amounts of protein were reacted with Z-DEVD-amino-4-methyl coumarin (AMC) substrate according to the manufacturer's instructions (Molecular Probes, Eugene, OR, USA). Reactions were performed in duplicate, with and without the specific inhibitor Ac-DEVD-CHO. 
Fluorescence at $460 \mathrm{~nm}$ was measured over $30 \mathrm{~min}$ at $30^{\circ} \mathrm{C}$ in a fluorometer with excitation at $380 \mathrm{~nm}$.

\section{Acknowledgements}

We gratefully acknowledge our colleagues Drs Anne-Catherine Andres and Andrew Ziemiecki for many fruitful discussions and much useful advice. In particular, we thank them for assistance in preparing affinitypurified polyclonal rabbit antibodies directed against DDC-4/sFRP-4. This work was supported by Grant No. 31-63-700.00 from the Swiss National Science Foundation (to RF), and for grants from the Bernese Cancer League (to RF) and from the Swiss Foundation for Clinical-Experimental Tumor Research (to RF).

\section{References}

1. Strange R, Li F, Saurer S, Burkhardt A and Friis RR (1992) Programmed cell death and tissue remodelling during mouse mammary gland involution. Development 115: 49-58

2. Li Feng, Bielke W, Guo K, Andres AC, Jaggi R, Friis RR, Niemann H, Bemis L, Geske FJ and Strange R (1995) Isolation of cell death-associated cDNAs from involuting mouse mammary epithelium. Cell Death Differ. 2: 113-122

3. Bielke W, Guo K, Feng Z, Bührer S, Saurer S and Friis RR (1997) Apoptosis in the rat mammary gland and ventral prostate: detection of "cell death"associated genes using a coincident-expression cloning approach. Cell Death and Differ. 4: 114-124

4. Wolf V, Guo KE, Dharmarajan AM, Bielke W, Artuso L, Saurer S and Friis $R$ (1997) DDC-4, an apoptosis-associated gene, is a secreted frizzled relative. FEBS Lett. 417: 385-389

5. Korinek V, Barker N, Morin PJ, van Wichen D, de Weger R, Kinzler KW, Vogelstein B and Clevers $\mathrm{H}$ (1997) Constitutive transcriptional activation by a $\beta$-catenin-Tcf complex in $\mathrm{APC}^{-1-}$ colon carcinoma. Science 275: 1784-1787

6. He TC, Sparks AB, Rago C, Hermeking H, Zawel L, da Costa LT Morin PJ, Vogelstein B and Kinzler KW (1998) Identification of C-MYC as a target of the APC pathway. Science 281:1509-1512

7. Tetsu $O$ and McCormick $F(1999)$ Beta-catenin regulates expression of cyclin D1 in colon carcinoma cells. Nature $398: 422-426$

8. Shtutman M, Zhurinsky J, Simcha I, Albanese C, D'Amico M, Pestell R and Ben-Ze'ev A (1999) The cyclin D1 gene is a target of the beta-catenin/LEFpathway. Proc. Natl. Acad. Sci. USA 96: 5522-5527

9. Mann B, Gelos M, Siedow A, Hanski ML, Gratchev A, llyas M, Bodmer WF Moyer MP, Riecken EO, Buhr HJ and Hanski C (1999) Target genes of betacatenin-T cell-factor/lymphoid-enhancer-factor signaling in human colorectal carcinomas. Proc. Natl. Acad. Sci. USA 96: 1603-1608

10. Peifer M (1997) $\beta$-Catenin as oncogene: the smoking gun. Science 275: 17521753

11. Nusse R, Samos CH, Brink M, Willert K, Cadigan KM, Wodarz A, Fish M and Rulifson E (1997) Cell culture and whole animal approaches to understanding signaling by Wnt proteins in Drosophila. Cold Spring Harb. Symp. Quant. Biol. 62: $185-190$

12. Finch PW, He X, Kelley MJ, Üren A, Schaudies RP, Popescu NC, Rudikoff S, Aaronson SA, Varmus HE and Rubin JS (1997) Purification and molecular cloning of a secreted, Frizzled-related antagonist of Wnt action. Proc. Natl. Acad. Sci. USA 94: 6770-6775

13. Rattner A, Hsieh J-H, Smallwood PM, Gilbert DJ, Copeland NG, Jenkins LC and Nathans J (1997) A family of secreted proteins contains homology to the cysteine-rich ligand-binding domain of frizzled receptors. Proc. Natl. Acad. Sci. USA 94: 2859-2863

14. Abu-Jawdeh G, Comella N, Tomita Y, Brown L, Tognazzi K, Sokol SY and Kocher $O$ (1999) Differential expression of frpHE: a novel human stromal protein of the secreted frizzled gene family, during the endometrial cycle and malignancy. Lab. Invest. 79: 439-447

15. Stewart TA, Pattengale PK and Leder P (1984) Spontaneous mammary adenocarcinomas that carry and express the MTV/myc fusion gene. Cell 38 : $627-637$
16. Pear WS, Nolan GP, Scott ML and Baltimore D (1993) Production of high-titer helper-free retroviruses by transient transfection. Proc. Natl. Acad. Sci. USA 90: 8392-8396

17. Edwards PAW, Abram CL and Bradbury JM (1996) Genetic manipulation of mammary epithelium by transplantation. J. Mammary Gland Bio. Neoplasia 1: $75-90$

18. Hennighausen L (2000) Mouse models for breast cancer. Oncogene 19: 966967

19. Guenette RS, Corbeil HB, Leger J, Wong K, Mezl V, Mooibroek M and Tenniswood M (1994) Induction of gene expression during involution of the lactating mammary gland of the rat. J. Mol. Endocrinol. 12: 47-60

20. Leder A, Pattengale PK, Kuo A, Stewart TA and Leder P (1986) Consequences of widespread deregulation of the c-myc gene in transgenic mice: multiple neoplasms and normal development. Cell 45: 485-495

21. Marti A, Graber H, Lazar H, Ritter PM, Baltzer A, Srinivasan A and Jaggi $R$ (2000) Caspases: decoders of apoptotic signals during mammary involution. Caspase activation during involution. Adv. Exp. Med. Biol. 480: 195-201

22. Bradbury JM, Edwards PA, Niemeyer CC and Dale TC (1995) Wnt-4 expression induces a pregnancy-like growth pattern in reconstituted mammary glands in virgin mice. Dev. Biol. 170: 553-563

23. Brisken C, Heineman A, Chavarria T, Elenbaas B, Tan J, Dey SK, McMahon JA, McMahon AP and Weinberg RA (2000) Essential function of Wnt-4 in mammary gland development downstream of progesteron signaling. Genes Dev. 14: 650-654

24. Wilde CJ, Addey CV, Bryson JM, Finch LM, Knight CH and Peaker M (1998) Autocrine regulation of milk secretion. Biochem. Soc. Symp. 63: $81-90$

25. Nguyen AV and Pollard JW (2000) Transforming growth factor $\beta 3$ induces cell death during the first stage of mammary gland involution. Development 127: 3107-3118

26. Gilmore AP, Metcalfe AD, Romer LH and Streuli CH (2000) Integrin-mediated survival signals regulate the apoptotic function of Bax through its conformation and subcellular localization. J. Cell. Biol. 149: 431-446

27. Lund LR, Romer J, Thomasset N, Solberg H, Pyke C, Bissell MJ, Dano K and Werb Z (1996) Two distinct phases of apoptosis in mammary gland involution: proteinase-independent and -dependent pathways. Development 122: 181193

28. Prince JM, Klinowska TC, Marshman E, Lowe ET, Mayer U, Miner J, Aberdam D, Vestweber D, Gusterson B and Streuli CH (2002). Cell - matrix interactions during development and apoptosis of the mouse mammary gland in vivo. Dev. Dyn. 4: 497-516.

29. Tonner E, Barber MC, Allan GJ, Beattie J, Webster J, Whitelaw CB and Flint DJ (2002) Insulin-like growth factor binding protein - 5 (IGFBP-5) induces premature cell death in the mammary glands of transgenic mice. Development 129: 4647-4557

30. Marti A, Jaggi R, Vallan C, Ritter PM, Baltzer A, Srinivasan A, Dharmarajan AM and Friis RR (1999) Physiological apoptosis in hormone-dependent tissues: involvement of caspases. Cell Death and Differ. 6: 1190-1200

31. Nusse R and Varmus HE (1992) Wnt genes. Cell 69: 1073-1087

32. Lin K, Wang S, Julius MA, Kitajewski J, Moos M and Luyten FP (1997) The cysteine-rich frizzled domain of Frzb-1 is required and sufficient for modulation of Wnt signaling. Proc. Natl. Acad. Sci. USA 94: 11196-11200

33. Andres AC, Bchini O, Schubaur B, Dolder B, LeMeur M and Gerlinger P (1991) $\mathrm{H}$-ras induced transformation of mammary epithelium is favoured by increased oncogene expression or by inhibition of mammary regression. Oncogene 6 : $771-779$

34. Jäger R, Herzer, U, Schenkel J and Weiher H (1997) Overexpression of Bcl-2 inhibits alveolar cell apoptosis during involution and accelerates c-myc induced tumorigenesis of the mammary gland in transgenic mice. Oncogene 15:17871795

35. Datta SR, Brunet A and Greenberg ME (1999) Cellular survival: a play in three Akts. Genes Dev. 13: 2905-2927

36. Alessi DR, Andjelkovic M, Caudwell B, Cron P, Morrice N, Cohen P and Hemmings BA (1996) Mechanism of activation of protein kinase $B$ by insulin and IGF-1. EMBO J. 15: 6541-6551

37. Alessi DR, James SR, Downes CP, Holmes AB, Gaffney PR, Reese CB and Cohen $P$ (1997) Characterization of a 3-phosphoinositide-dependent protein 
kinase which phosphorylates and activates protein kinase B-alpha. Curr. Biol. 7: 261-269

38. Stokoe D, Stephens LR, Copeland T, Gaffney PR, Reese CB, Painter GF, Holmes AB, McCormick F and Hawkins PT (1997) Dual role of phosphatidylinositol-3,4,5-trisphosphate in the activation of protein kinase $B$. Science 277: $567-570$

39. Datta SR, Dudek H, Tao X, Masters S, Fu H, Gotoh Y and Greenberg ME (1997) Akt phosphorylation of BAD couples survival signals to the cell-intrinsic death machinery. Cell 91: 231-241

40. Sharma M, Chuang WW and Sun Z (2002) Phosphatidylinosital 3-kinase/Akt stimulates androgen pathway through GSK3beta inhibition and nuclear betacatenin accumulation. J. Biol. Chem. 277: 30935-30941

41. Grimes CA and Jope RS (2001) The multifaceted roles of glycogen synthase kinase 3-beta in cellular signaling. Prog. Neurobiol. 65: 391-426

42. King TD, Bijur GN and Jope RS (2001) Caspase-3 activation induced by inhibition of mitochondrial complex I is facilitated by glycogen synthase kinase3-beta and attenuated by lithium. Brain Res. 919: 106-114

43. Song DH, Sussman DJ and Seldin DC (2000) Endogenous protein kinase CK2 participates in Wnt signaling in mammary epithelial cells. J. Biol. Chem. 275: 23790-23797

44. Fukumoto S, Chung-Ming H, Maemura K, Layne MD, Shaw-Fang Y, KyungHan Lee, Matsui T, Rosenzweig A, Taylor WG, Rubin JS, Perrella MA and MuEn L (2001) Akt participation in the Wnt signaling pathway through dishevelled. J. Biol. Chem. 276: 17479-17483

45. Guo K, Wolf V, Dharmarajan AM, Feng Z Liwei, Bielke W, Saurer S and Friis R (1998) Apoptosis-associated gene expression in the corpus luteum of the rat. Biol. Reprod. 58: 739-746
46. Sabbatini P and McCormick F (1999) Phosphoinositide 3-OH kinase (PI3K) and PKB/Akt delay the onset of p53-mediated, transcriptionally dependent apoptosis. J. Biol. Chem. 274: 24263-24269

47. Morgenstern JP and Land $H$ (1990) Advanced mammalian gene transer: High titre retroviral vectors with multiple drug selection markers and a complementary helper-free packaging cell line. Nucleic Acids Res. 18: 3587-3596

48. Reichmann E, Ball R, Groner B and Friis RR (1989) New mammary epithelial and fibroblastic cell clones in co-culture form structures competent to differentiate functionally. J. Cell Biol. 108: 1127-1138

49. Strange R, Li F, Friis RR, Reichmann E, Haenni B and Burri PH (1991) Mammary epithelial differentiation in vitro: minimum requirements for a functional response to hormonal stimulation. Cell Growth Differ. 2: 549-559

50. Laemmli, UK (1970) Cleavage of structural proteins during the assembly of the head of bacteriophage T4. Nature 227: 680-685

51. Jaggi R, Salmons B, Muellener D and Groner B (1986) The v-mos and Ha-ras oncogene expression represses glucocorticoid hormone dependent transcription from the mouse mammary tumor virus LTR. EMBO J. 5: 26092616

52. Chomczynski P and Sacchi N (1987) Single-step method of RNA isolation by acid guanidinium thiocyanate-phenol-chloroform extraction. Anal. Biochem. 162: $156-159$

53. Nemes Z, Friis RR, Aeschlimann D, Saurer S, Paulsson M and Fesus L (1996) Expression and activation of tissue transglutaminase in apoptotic cells of involuting radent mammary tissue. Eur. J. Cell Biol. 70: 125-133 